\title{
BENTHIC BIOLOGY TIME-SERIES IN THE DEEP-SEA: INDICATORS OF CHANGE
}

K.E. Larkin ${ }^{(1)}$, H.A. Ruhl ${ }^{(1)}$, P. Bagley ${ }^{(2)}$, A. Benn ${ }^{(1)}$, B.J. Bett ${ }^{(1)}$, D.S.M. Billett ${ }^{(1)}$, A. Boetius ${ }^{(3)}$, P. Chevaldonné(4) A. Colaço $^{(5)}$, J. Copley ${ }^{(1)}$, R. Danovaro ${ }^{(6)}$, E. Escobar-Briones ${ }^{(7)}$, A. Glover $^{(8)}$, A.J. Gooday ${ }^{(1)}$, J.A. Hughes ${ }^{(1)}$, V. Kalogeropoulou ${ }^{(9)}$, B.A. Kelly-Gerreyn ${ }^{(1)}$, H. Kitazato ${ }^{(10)}$, M. Klages ${ }^{(11)}$, N. Lampadariou ${ }^{(9)}$, C. Lejeusne $^{(4)}$, T. Perez ${ }^{(4)}$, I.G. Priede ${ }^{(2)}$, A. Rogers ${ }^{(12)}$, P.M. Sarradin ${ }^{(13)}$, J. Sarrazin ${ }^{(13)}$, T. Soltwedel ${ }^{(13)}$, E.H. Soto ${ }^{(14)}$, S. Thatje ${ }^{(1)}$, A. Tselepides ${ }^{(15)}$, P.A. Tyler ${ }^{(1)}$, S. van den Hove ${ }^{(16)}$, A. Vanreusel $^{(17)}$, F. Wenzhöfer ${ }^{(3)}$

${ }^{(1)}$ National Oceanography Centre, Southampton, University of Southampton Waterfront Campus, European Way, Southampton, SO14 3ZH, (U.K.), Email: kel1@noc.soton.ac.uk; h.ruhl@noc.soton.ac.uk;

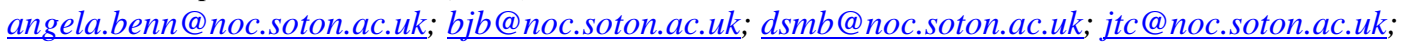
ang@noc.soton.ac.uk; jyh@noc.soton.ac.uk; bag@noc.soton.ac.uk; syth@noc.soton.ac.uk; pat8@noc.soton.ac.uk

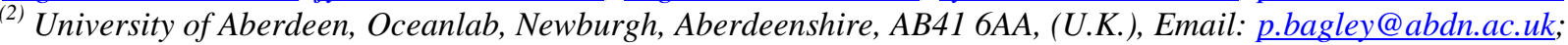
i.g.priede@abdn.ac.uk

${ }^{(3)}$ Max Planck Institute for Marine Microbiology, Celsiusstr. 1, 28359 Bremen (Germany), Email:aboetius@mpi-bremen.de; fwenzhoe@mpi-bremen.de

${ }^{(4)}$ Centre d'Océanologie de Marseille, Station Marine d'Endoume, Rue de la Batterie des Lions - 13007 Marseille, (France), Email: pierre.chevaldonne@univmed.fr; christophe.lejeusne@univmed.fr; thierry.perez@univmed.fr

${ }^{(5)}$ Department of Oceanography and Fisheries, Campus of Horta, Cais de Santa Cruz, 9901 -862 Horta, Açores, (Portugal), Email: acolaco@uac.pt

${ }^{(6)}$ Department of Marine Science, Polytechnic University of Marche, Via Brecce Bianche, 60131 Ancona (Italy), Email: r.danovaro@univpm.it

(7) Universidad Nacional Autonoma de México, Instituto de Ciencias del Mar y Limnologia, Unidad Académica Ecología Marina, Laboratorio Biodiversidad y Macroecologia, A.P. 70-305 Ciudad Universitaria, 04510 México, D.F. (México),Email: escobri@cmarl.unam.mx

${ }^{(8)}$ Natural History Museum, Cromwell Road, London, SW7 5BD, (U.K.), Email: a.glover@nhm.ac.uk

${ }^{(9)}$ Hellenic Centre for Marine Research (HCMR), Institute of Oceanography, PO Box 2214, 71003 Heraklion, Crete, (Greece) Email: vkalogeropoulou@her.hcmr.gr; nlamp@her.hcmr.gr

${ }^{(10)}$ Institute of Biogeosciences, Japan Agency for Marine-Earth Science and Technology, 2-15 Natsushima-cho, Yokosuka 237-0061, (Japan), E-mail kitazatoh@jamstec.go.jp

${ }^{(11)}$ Alfred Wegener Institute Am Handelshafen 12, D-27570 Bremerhaven, (Germany), Email: Michael.Klages@awi.de; thomas.soltwedel@awi.de

${ }^{(12)}$ Institute of Zoology, Zoological Society of London, Regent's Park, London, NWI 4RY (U.K.), Email: alex.rogers@ioz.ac.uk

(13) IFREMER (French Institute for Exploitation of the Sea/Institut Français de Recherche pour l'Exploitation de la Mer) DEEP/LEP (Département Études des Écosystèmes Profonds/Laboratoire Environnement Profond), Centre de Brest, BP 70, 29280 Plouzané, (France), Email: pierre.marie.sarradin@ifremer.fr; Jozee.Sarrazin@ifremer.fr

(14) Facultad de Ciencias del Mar y de Recursos Naturales, Universidad de Valparaíso, Casilla 5080 Reñaca, Viña del Mar, (Chile), Email: eulogio@noc.soton.ac.uk

(15) Univ. of Piraeus, Dept. of Maritime Studies, Piraeus 185 32, (Greece), E-mail: tselepi@unipi.gr

${ }^{(16)}$ MEDIAN SCP, Passeig Pintor Romero, 808197 Valldoreix, (Spain), Email: sybille@median-web.eu

(17) Ghent University, Marine Biology Research group, Sterre Campus, Krijgslaan 281 (S8), B-9000 Ghent, (Belgium), Email: Ann.Vanreusel@ugent.be

\section{ABSTRACT}

The responsiveness of benthic biological communities to climatic drivers and shifts makes them powerful indicators of biogeochemical and other environmental change in the oceans. In addition, benthic ecosystems have an economic value and are considered a vital marine resource. However deep-sea faunal dynamics and ecosystem functioning is not well defined. This has placed a higher priority in recent years on developing and sustaining long-term, time-series studies of benthic biodiversity, rate processes, and ecosystem change in deep-sea and extreme habitats. A few key long-term time-series sites exist across the global Ocean. Many of these sites are reviewed in this paper. However, much of the existing research is uncoordinated and the data collected are not integrated or standardized. This currently limits the use of these valuable datasets, which could be used for benthic modeling, global model validation and other societal benefits related to more effective and environmentally sustainable governance of human activities in the deep ocean. Furthermore, the time scales that can be studied within existing research frameworks are not currently sufficient to adequately address internationally-identified science priorities. 
These include assessing regional and global biodiversity, ecosystem functioning and the links between climate, terrestrial and marine ecosystems. In addition, the contribution of deep-sea ecosystems to global biogeochemical cycles and the potential alteration to ecosystem value and services due to anthropogenic activities is largely unknown. In order to maximize the societal benefit, biological time-series, in particular deep-sea sites, urgently require more coordination, integration, sustained funding and infrastructure. This is necessary to unify research methodologies, create synergies in the use of deep-sea technology, develop benthic models, and to stimulate more collaboration between programmes. National and international research organizations may provide a suitable framework within which further advances can be achieved. Only then will we better understand the goods and services provided by deep-sea ecosystems and the potential for environmentally sustainable exploitation of the deep ocean.

\section{INTRODUCTION}

\subsection{Content and aims}

Long-term high resolution time-series studies are vital to understand the diverse range of processes that occur in the deep-sea. These range from short-term processes such as daily, seasonal and inter-annual variations, to longer-term trends including those linked to climate change, to centennial- and millennial-scale changes that can only be addressed by studying the deep-sea fossil record. While sampling from research ships offers a detailed snapshot of the biogeochemistry and biology of deep-sea ecosystems, temporal processes and cycles can only be addressed through continuous high-resolution measurements and sampling. For instance, sustained benthic biological time-series provide information that is crucial for understanding ecological processes in the deep ocean, including those involved in global biogeochemical cycling. In addition, continuous observation is the only method to capture periodic or episodic events such as mud slides and phytodetrital deposition, which are difficult to predict accurately. Without a permanent observing system, these events are often missed or their importance misinterpreted. An established and sustained observing system is particularly vital for the deep-seafloor (>1000 m water depth), as it is less accessible than shallow water or coastal environments, and routine, opportunistic or fastresponse sampling is difficult and expensive. Timeseries research (e.g. from ocean observatories) does not stand alone but complements and provides important verification for spatial analyses (e.g. from Autonomous Underwater Vehicles and Remotely Operated Vehicles). Combining these temporal and spatial datasets allows complex dynamic processes to be more fully understood.

Thanks to the development and implementation of the Global Ocean Observing System (GOOS), the past decade has seen the development of routine measurements of the physical ocean at high resolution across a global network. However, there is a critical need to bridge observational gaps in the climate observing system to include biological and biogeochemical measurements. Areas currently undersampled or without a global coverage of sustained observations include carbon budgets, ocean acidification and the identification and estimation of biodiversity [1]. In many cases deep-sea biological time-series can address these gaps. In addition, more links must be made between global observing outputs and socioeconomic data to address societal needs and the economics of ecosystem services.

Key questions currently remain: if important global environmental changes occur, will they and their impact on life in the oceans be discernable, and how will changes in the surface ocean affect deep-seafloor ecosystems and their potential societal benefit? Technological advances in the past two decades have enabled exploration and observing platforms and systems to be established in the deep-sea. Developments in observational technologies have led to the discovery of chemosynthetic environments and other 'hot-spot' regions for biodiversity, including submarine canyons and seamounts. Advances have also been made in the in situ measurement of chemical and biological parameters over long periods in the open ocean and deep-sea. 


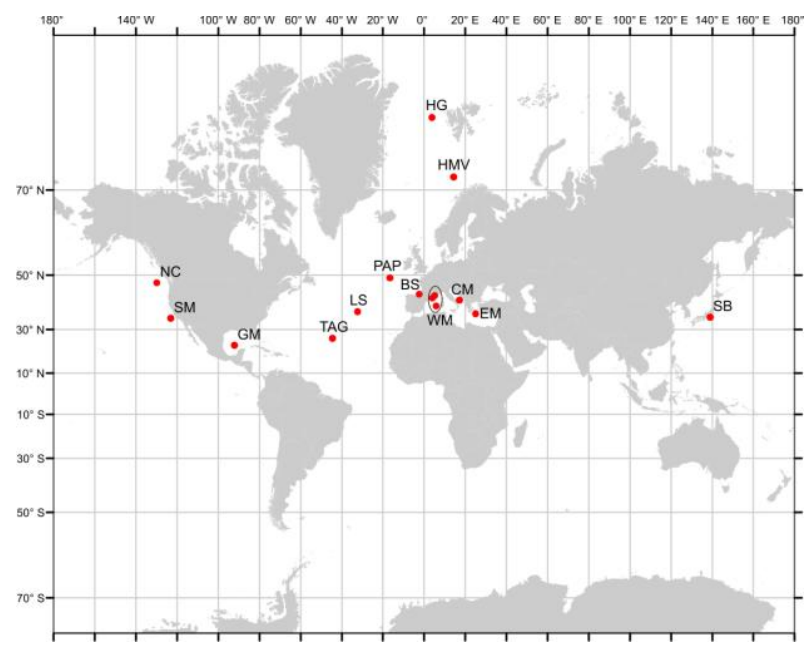

Figure 1. Location map of selected key Long-term reference stations for seafloor biological observations. See Tab. 1. for more information on sites. Key: $P A P=$ Porcupine Abyssal Plain, WM=Western Mediterranean (including Catalan margins Cap de Creus canyon CCC sites, $C 1$ and the shallow marine cave 3PP), CM=Central Mediterranean (Bari Canyon N. Branch, Dauno Seamount, Gondola side), EM=East Mediterranean (Bathysal Mediterranean sedimentCretan Sea and Ierapetra Basin, D7),

$H G=H A U S G A R T E N, S M=$ Station $M$ and Monterey

Bay, TAG=Trans-Atlantic Geotraverse, $S B=$ Sagami

Bay and Trough, LS=Lucky Strike, NC=NEPTUNE Canada, GM=Gulf of Mexico, BS=Biscay Slope, $H M V=$ Haakon Mosby Mud Volcano.

This paper reviews results from key time-series sites across the global Ocean where long-term, time-series research on deep-sea benthic ecosystems has been conducted. This includes sites driven by both photosynthetic (upper ocean) and chemosynthetic (subseafloor) processes (Fig. 1; Tab. 1). Future efforts to integrate and coordinate benthic ecosystem sampling into a global network of ocean observation are discussed along with the expected added value of integrating the resulting datasets to contribute to the global ocean observation system. In addition, this paper provides 1) a rationale for sustaining deep-sea benthic biological time-series and, in some cases, enhancing them to form more permanent deep-sea biological observatories, and 2) a vision for integrating time-series datasets and the infrastructure and technology required to maintain and enhance these observations. We aim to represent a consensus view of the international deep-sea benthic biology community and above all to provide a rationale in terms of societal benefits for sustaining and further developing these time-series. We refer the reader to key references including [2] which reviews key long-term benthic biological reference sites within the DEEPSETS (Deep-sea \& Extreme Environments, Patterns of Species and Ecosystem Time Series) MarBEF (Marine
Biodiversity and Ecosystem Functioning) project and the Climatic and geological drivers of long-term temporal change in deep-sea ecosystems and [3] a UNEP (United Nations Environment Programme) report, which considers and evaluates the socioeconomics of deep-sea biological resources and environments.

\subsection{Scientific rationale for deep-sea ecosystem observations}

Strong evidence has emerged in recent decades that the deep-sea environment is not as stable or isolated as previously thought. Rather, the deep-sea is influenced by episodic events such as pulses of sinking particles derived from surface production, carrion falls and periods of elevated current activity that disturb the seabed [4], [5], [6], [38], [39], [40] and [44]. There are apparent links between climate, the upper ocean and the deep-sea, especially in terms of climate-driven variations in food availability and consequent shifts in faunal communities (Fig. 2) [52] and [53] and trophic cascading. This responsiveness suggests that deep-sea benthic fauna are key indicators of the oceans' response to climate change and associated changes occurring in the water column [7]. Moreover, links between surface conditions and deep-sea ecosystems have poorly understood implications for carbon cycling and other biogeochemical processes. Datasets indicate that variations in physico-chemical conditions and particulate organic carbon fluxes drive variations in biodiversity and biogeochemical cycling in deep-sea sedimentary ecosystems, over both annual and interannual time scales. But many questions remain unanswered. For example, it is not known even to a first order, whether long-term changes in carbon fluxes will change the proportions of carbon that are remineralised and released back into the water column or geologically sequestered.

Changes observed at hydrothermal vent and cold seep systems, fueled by chemical energy sources from Earth's interior, have significant links to solid Earth dynamics. These trigger major environmental shifts over relatively short (inter-annual) time scales. The circulation of hydrothermal fluids at mid-ocean ridges is a parallel process that influences the transfer of energy and matter from the interior of the Earth to the crust, hydrosphere and biosphere. The unique faunal communities that develop near hydrothermal vents are sustained by chemosynthetic microorganisms that use chemicals in the hot fluids as a source of energy. Geological processes at active mid-ocean ridges can create changes in the flux, composition and temperature of emitted hydrothermal fluids, and the location of vent openings that largely control the structure and distribution of the associated faunal communities. Hydrothermal circulation also accounts for approximately one third of the global geothermal heat 
flux to the ocean and strongly affects the chemical composition of seawater. Substantial changes in community composition and distribution on time scales of months to years have been observed in hydrothermal

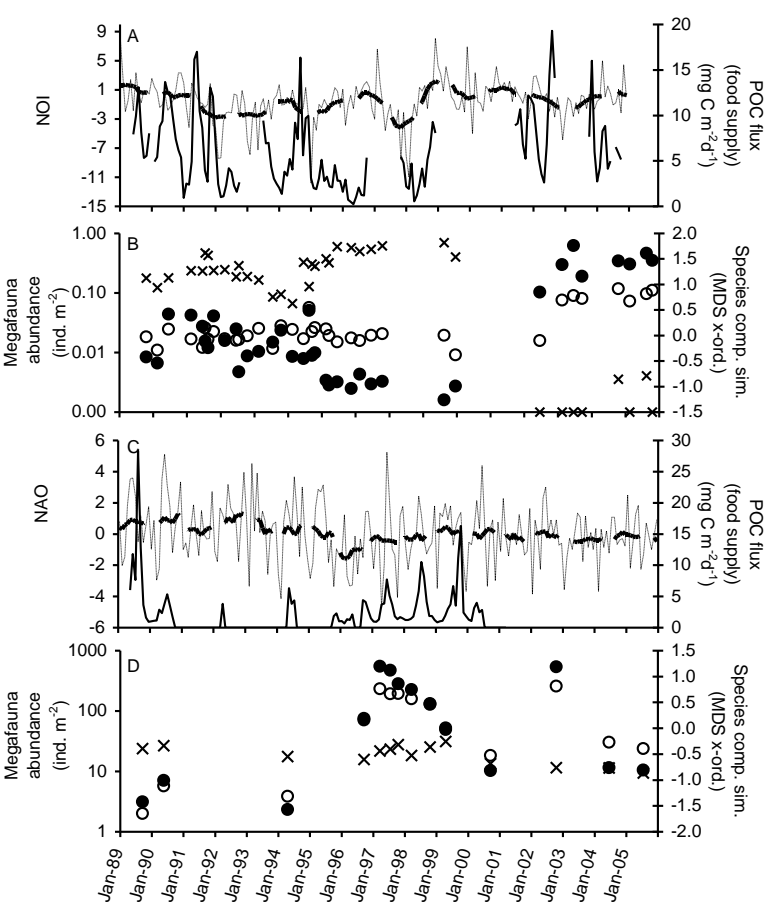

Figure 2. Climatic and abyssal time-series data for Station $M$ in the NE Pacific and PAP in the NE Atlantic with A) the ENSO (El Niño/Southern Oscillation) indicator the Northern Oscillation Index (NOI) with monthly (light dashed line) and 13-month running mean (bold dashed line), and POC (Particulate Organic Carbon) flux to $4050 \mathrm{~m}$ depth at Sta. M; B) mobile megafauna variation at Sta. M including Elpidia minutissima abundance (crosses), Echinocrepis rostrata abundance (open circles), and an index of species composition similarity of the top ten most abundant megafauna (solid circles); C) the North Atlantic Oscillation (NAO) index with monthly (light dashed line) and 13-month running mean (bold dashed line), and POC flux to $3000 \mathrm{~m}$ depth at the PAP; and D) total megafauna variation at Sta. $M$ including Oneirophanta mutabilis abundance (crosses), Amperima rosea abundance (open circles), and an index of species composition similarity of the benthic megafauna (solid circles) (from [2], [7], [40], [52] and [53]).

ecosystems (reviewed in [2]), but the relative roles of environmental conditions, biological interactions and stochastic processes remain poorly understood [8], 9], [10], [11] and [12], in part due to the absence of continuous monitoring. In addition to venting, energyrich fluids can seep from sub-seafloor sediments. These areas, known broadly as cold seeps, also harbour chemosynthetic communities with complex biogeochemical roles, such as providing a sink for methane and sulfides [13] and [14].
Progressive trends in deep-sea ecosystems have been recorded that could be linked to climatic forcing. Other sites are impacted by stochastic events. Evidence for linking biosphere responses to major climatic shifts is also found throughout the geological record [2]. More coordination of this research will allow major research issues, such as the how ocean productivity and deep-sea processes relate to organism distribution, biodiversity, and function in seafloor ecosystems, to be addressed at the global level.

\subsection{The socio-economic importance of deep-sea ecosystems}

Deep-sea ecosystems provide a number of important ecosystem functions. These can be defined as "processes, products or outcomes arising from biogeochemical activities" [15]. For example, there is evidence that in photosynthetically derived systems, the benthic biodiversity, abundance and ecosystem functioning is affected and possibly driven by the variation in the quality and quantity of surface-derived organic matter arriving on the seafloor [6], [16], [21], [22], [39] and [40]. Understanding this link between benthic biological communities and climatic drivers and shifts offers the potential for their use as indicators of biogeochemical and other environmental change in the oceans. The deep-sea also provides a range of ecosystem goods and services (i.e. human benefits directly or indirectly derived from ecosystem functions). For example, maintenance of biodiversity is thought to be essential to ecosystem stability, so that loss of species may detrimentally influence ecosystem function [16], and therefore the provision of goods and services [3]. Attaching a monetary value to ocean-floor communities is problematic for several reasons. These include the limited knowledge of the nature of deep-sea ecosystems and the goods and services they provide, the complexity of the ecological processes and the broad scales in time and space over which they operate. As a result, valuation methods based on preferences are likely to be biased or irrelevant [3] (Tab. 2).

Certain components of the Total Economic Value (TEV) of the deep-seas, such as oil and gas extracted or fish harvested, are relatively straightforward to value through market prices. This approach has a number of disadvantages, however; for example, the many deepwater biotic resources (species) have such slow growth rates that their exploitation is similar to that of abiotic resources; that is, they should be considered as nonrenewable [17]. While deep-sea trawling may provide food and employment, the environmental cost and sustainability of this activity is unclear. For example, the 2006 global high seas bottom fisheries catch of 250,000 tonnes represented only $0.3 \%$ of the global total marine catch with 285 vessels operating, mostly part time [18]. Likewise, before we can value say the supporting services (chemosynthetic primary 
production) and provisioning services (mineral and biochemical resources) of hydrothermal vents or cold seeps, we need a better understanding of their environmental role [3]. In summary, we still do not have the knowledge basis to be able to identify and understand all the goods and services provided by the deep-sea and its ecosystems, and all the various aspects of their value. We are far from being able to integrate their values in support of decision-making.

\begin{tabular}{|l|l|l|}
\hline \multicolumn{3}{|c|}{ Use values } \\
\hline Direct use value & Indirect use value & Option use value \\
\hline Fish, & nutrient & Potential drugs, \\
oil, & cycling, gas & chemicals \\
gas, & and climate & and biopolymers \\
minerals, & regulation, & for future industrial \\
waste dumps & carbon & or pharmaceutical \\
military submarine & sequestration, & and biotechnological \\
routes & abatement of & applications \\
& waters & \\
\hline
\end{tabular}

\begin{tabular}{|l|l|}
\hline \multicolumn{2}{|c|}{ Non use values } \\
\hline Bequest value & \multicolumn{1}{|c|}{ Existence value } \\
\hline preserving & knowing that \\
the deep-sea & deep-sea \\
environment & environments \\
for future & exist \\
generations & \\
\hline
\end{tabular}

Table 2: Total Economic Value components and Deepsea examples (adapted from [3])

\section{GLOBAL DEEP-SEA BIOLOGICAL TIME- SERIES SITES: HIGHLIGHTS FROM DETRITUS-DERIVED AND CHEMOSYNTHETICALLY DERIVED SITES}

The following section reviews some key long-term benthic biological time-series sites. [2] provide a detailed review of longer-term faunal change in the deep-sea. Most of the following highlights are based largely on this synthesis. See Fig. 1 and Tab. 1 for a location map and further details on each site.

\subsection{Sites with photosynthetically-derived food supplies}

\subsubsection{Biscay slope}

Two sites on the slope of the Bay of Biscay have been sampled over a multi-annual period in order to investigate temporal fluctuations in benthic foraminiferal assemblages. A 550-m site was sampled between 1997 and 2000 [19] and a 1000-m site between 1997 and 2001 [20]. These studies suggested that temporal changes could be distinguished from spatial variability. However, this region is subject to a strong spring bloom and the temporal fluctuations were largely intra-annual and concerned opportunistic species that responded to phytodetritus deposition. The lack of evidence for longer-term faunal trends at either of these sites illustrates the difficulties involved in distinguishing such trends from the noise created by spatial and seasonal variability, particularly in the case of time series of sub-decadal length.

\subsubsection{Sagami Bay}

Observations of both water column and seafloor have been conducted in Sagami Bay for over 15-years, with a permanent station located at $1450 \mathrm{~m}$ depth [21], [22] and [23]. Long-term datasets of the benthic community indicate distinct decreases in population size of benthic foraminifera during the El Niño years 1996 and 1997. Average abundances decreased from 4200 individuals $10 \mathrm{~cm}^{-2}$ to 2500 individuals $10 \mathrm{~cm}^{-2}$ over this year, indicating the rapid response of benthic organisms to environmental conditions. It is not yet clear how faunal density is affected by longer-term trends (e.g. climate change and/or ocean acidification). These data, in combination with other time-series data available on material transportation and carbon cycling, have made it possible to evaluate the responses of deep-sea organisms to environmental changes. Effects of human impacts on the ecology of the area are apparent; for example, [24] analysed fluorescent whitening agents (FWAs) in sediments from both Tokyo Bay and Sagami Bay. They detected high concentrations of FWAs in Tokyo Bay sediments and Polychlorinated biphenyls (PCBs) in benthic faunal tissues. Several innovative approaches are proposed to continue monitoring deepsea environments and organisms in Sagami Bay, including the use of a cabled network and frequent ROV (Remotely Operated Vehicle) and AUV (Autonomous Underwater Vehicle) visits. Sagami Bay also has a parallel chemosynthetic environment called Sagami Trough (Sect. 2.2).

\subsubsection{Western Mediterranean (Catalan margins)}

Submarine canyons can be subjected to strong Dense Shelf Water Cascading (DSWC) episodes induced by climatic variations. These sudden events have a considerable impact on seafloor communities that lie in their path. An investigation carried out along a bathymetric transect (900-2400 m) located in the Cap de Creus Canyon in the Catalan margins (April and October 2005, August 2006) revealed that a DSWC episode in winter 2004-05 flushed a large amount of organic material from the upper canyon to its deepest part. This event physically disturbed the seafloor and caused substantial changes in the structure and functioning of the canyon ecosystem [25]. It has been proposed recently that this type of cascading event can link climate variation and slope processes to deep-sea fisheries [26] and [27]. 


\subsubsection{Central and Eastern Mediterranean Basin (South Adriatic and Cretan Sea)}

In the last two decades, the physico-chemical characteristics of Mediterranean deep waters have been modified, and this may be linked with climate change. This has occurred in two phases, the first between 1987 and 1992 when dense, relatively warm water formed in the south Aegean (Cretan Deep Water), and the second from 1992 to 1994 when there was a drop in the deepwater temperature of $c .0 .4^{\circ} \mathrm{C}$ that resulted in the formation of denser deep water. As a result of these changes, the eastern Mediterranean Deep and Bottom Waters were uplifted by several hundred metres and formed a distinct nutrient-rich intermediate-water layer that reached shallower depths (100-150 m; i.e. close to the euphotic zone). Extremely small amounts of organic matter reach the floor of the deep eastern Mediterranean, one of the most oligotrophic areas of the World Ocean. However, the observed upwelling of nutrient-rich deep waters generated increased biological production coupled with changes in the phytoplankton composition and average phytoplankton cell size. As a result, fluxes of phytodetritus and organic matter to deep-sea sediments were enhanced by up to two orders of magnitude in terms of protein accumulation; the total protein:carbohydrate ratio increased while the carbon:nitrogen ratio decreased. These changes altered the carbon and nitrogen cycles and were coupled to shifts in deep-sea prokaryotic metabolism and benthic faunal biomass [28].

The response of deep-sea nematode biodiversity to short (seasonal) and longer-term (interannual) change was investigated in the Central- Western Mediterranean basin (at 500-3000 m), in the Ierapetra Basin (at 2500$4500 \mathrm{~m}$ ) and in different habitats located in the Southern Adriatic (600- $830 \mathrm{~m}$ ) [16] and [29]. A decadal dataset (from 1989 to 2007) from $1540 \mathrm{~m}$ in the Cretan Sea suggests that nematode diversity can be strongly and rapidly affected by even minor temperature shifts [30]. The abrupt physical and chemical changes observed were coupled with a significant decrease in nematode abundance and a significant change in diversity. Such changes also resulted in altered functional diversity and increased the importance of the microbial components within the benthic food webs. In the Ierapetra Basin, data on pigment concentrations from surface sediments indicate that despite its oligotrophy, the eastern Mediterranean may occasionally experience periods of unusually high concentrations of phytopigments [31] causing significant changes in the abundance and composition of the meiobenthic [29] and [32] and the macrobenthic [33] communities.

\subsubsection{HAUSGARTEN}

This long-term, deep-sea observatory was established in 1999 to detect and track the impact of large-scale environmental changes in the transition zone between the northern North Atlantic and the central Arctic Ocean [34]. The observatory is located in the Fram Strait, the only deep connection between the Nordic Seas and the central Arctic Ocean, where exchanges of intermediate and deep waters take place. The advection of these waters exerts the main control on the climate of the Nordic Seas and the entire Arctic Ocean [35]. The observatory includes more than a dozen permanent sampling sites from 1000 to $5500 \mathrm{~m}$ depth and along a latitudinal transect following the $2500 \mathrm{~m}$ isobath. Multidisciplinary research activities at HAUSGARTEN cover almost all aspects of the marine ecosystem from the pelagic zone to the benthic realm, with a focus on benthic processes.

Particulate matter fluxes in the area show pronounced seasonal patterns and have a variable composition, derived from two major sources: export from the photic zone and lateral advection [36]. Results reveal that sea ice and material incorporated therein plays an important role in the dispersion of particulate matter of marine and terrestrial origin. Data from photographic images obtained in 2002 and 2004 show a significant decrease in megafauna densities at $2500 \mathrm{~m}$ water depth [2], probably due to decreased food availability. Meiofaunal densities show a high interannual variability at the same depth [37], but no consistent relationship was found over a 5-year period with measures of organic inputs.

Time-series studies at HAUSGARTEN have revealed trends including increases in deep-water temperature, decreasing flux of phytodetrital matter to the seafloor, and subsequently, a decreasing trend in sediment-bound organic matter and the total microbial biomass in the sediments. However, it remains unclear whether these indicate lasting alterations to the system or simply reflect natural multi-year variability (e.g. in relation to variations in the Arctic Oscillation). A sustained decrease in organic matter input would certainly affect the entire deep-sea ecosystem.

The HAUSGARTEN observatory is a key site within the European ESONET (European Seas Observatory NETwork) Arctic node and is also part of the EMSO (European Multidisciplinary Seafloor Observation) programme. Development plans at the site include the installation of a seafloor observatory network with local energy supply for short- and medium-term observations, measurements, and experiments and a cable connection of the HAUSGARTEN observatory to a land base (Koldewey Station, Spitsbergen) in 2011.

\subsubsection{Porcupine Abyssal Plain}

Research at the Porcupine Abyssal Plain Sustained Observatory site (PAP-SO; $4800 \mathrm{~m}$ depth) began in 1989 and has focused on understanding links between surface processes, the supply of Particulate Organic Carbon (POC) to the deep ocean (e.g. [38]), and the 
ecology of the benthic fauna,, as well as an ESONET NoE (Network of Excellence) Demonstration Mission and EMSO activity.

Benthic research at the site has revealed significant variations in faunal densities and community composition over seasonal and interannual timescales from small meiofauna to larger macro and megafaunal size classes. In many cases this impact can be related to the food quality and quality. The most noticeable change was amongst the megafauna, and particularly the small elasipod holothurian Amperima rosea, which increased in abundance by over three orders of magnitude after 1996 (the so-called Amperima event) and then declined more slowly [39] and [40]. Compared to the 1989-1994 period, total metazoan meiofaunal abundances increased significantly in 1996 and persisted through 1999 (ranging from a mean of 346 in 1989 to 1074 ind. $10 \mathrm{~cm}^{-2}$ in 1999). This pattern was driven mainly by the dominant taxon, the nematodes (representing $\sim 90 \%$ of total abundance), and to a lesser extent the polychaetes [41]. These changes paralleled those in other faunal groups. For example, there were stepwise increases in macrofaunal polychaete abundances [42], coinciding with the 'Amperima Event'. Significant differences were observed in some trophic groups (predators, surface deposit-feeders and burrowers) and the dominant families (Cirratulidae, Spionidae and Opheliidae). Changes in surface deposit feeders were particularly evident [43]. Rose-Bengal-stained ('live') benthic foraminifera were significantly more abundant in 1996-2002 compared to 1989-1994. Underlying this trend were changes in the densities of higher taxa and species. Trochamminaceans, notably a small undescribed species, increased substantially between 1989-1994 and 1996-2002 and species of Hormosinacea and Lagenammina also tended to increase in density from 1996/1997 onwards [44]. However, different species exhibited different temporal patterns over the course of the time series, prompting [44] to conclude that a variety of factors, some seasonal and some longer term, probably influenced temporal patterns among benthic foraminifera.

Community changes at the site have been attributed to climate-driven changes in POC flux quantity and quality. The North Atlantic Oscillation, for example, was linked to POC fluxes to the seafloor with a time lag of several months [45], as well as to megafauna community composition [40]. Notably, the observed ecosystem changes at PAP were linked with qualitative variations in the biochemistry of Particulate Organic Matter (POM) [39], which are believed to be critical to the reproductive and recruitment success of key species such as Amperima rosea [46]. Significant changes in bentho-pelagic fish distributions were also seen in area extending from Porcupine Abyssal Plain into the Porcupine Seabight [47].

\subsubsection{Gulf of Mexico}

A site in the Gulf of Mexico has been sampled in June every year since 1997 . The resulting data has documented the inter-annual variability of the benthic macrofauna. The long-term ecological research (LTER (Long Term Ecological Research)) station is located in the Sigsbee abyssal plain, at $3800 \mathrm{~m}$ water depth in the centre of the basin and characterized by tropical conditions. This area is partially connected to the Atlantic Ocean through the Florida Strait and with the Caribbean Sea through the Yucatan Channel [48]. The abyssal plain is characterized by well-oxygenated bottom waters with values ranging from 4.2 to $5 \mathrm{ml} \mathrm{O}_{2} \mathrm{l}^{-}$ ${ }^{1}$ and biogenic pelagic and hemipelagic clay sediments [49]. Environmental factors (water bottom temperature, salinity, dissolved oxygen, $\mathrm{pH}$, organic $\mathrm{C}$ and $\mathrm{N}$, and grain size) are recorded and evaluated annually [50] in conjunction with macrofaunal sampling.

Variations in macrofaunal densities were significant. Between 1997 and 2002 a peak occurred in 2000 more than 6 times larger than the lowest values recorded in 2001. Preliminary analysis suggests that this variability can be related to changes in the export of POC from the surface and climatic phenomena in the region (sensu [45]). These phenomena might include hurricane activity or the El Niño Southern Oscillation (ENSO), both of which modify the spatial and temporal characteristics of mixing, nutrient availability, seasurface temperature, and export flux [51] and [45]. These results demonstrate that the inter-annual variability in surface conditions is reflected in deep-sea faunal communities.

\subsubsection{Northeast Pacific (Station M and Monterey Bay)}

Abyssal research on benthic ecosystems has been conducted at a site in the NE Pacific (Station M; $4100 \mathrm{~m}$ depth) with a focus on understanding how climate influences surface conditions and abyssal POC fluxes and the influence of those fluxes on sediment chemistry and benthic communities from macro to megafauna. In addition, research has aimed to understand the relationship between organic carbon fluxes reaching the seafloor and respiration rates of the entire benthic community, a key measure of ecological function. Research at Station $M$ has identified temporal lags between climate variation and abyssal community shifts (Fig. 2). Climate variations related to the ENSO are linked to the export of POC from the euphotic zone to the abyssal seafloor, with a time lag of approximately six months between changes in climate and changes in POC fluxes [7] and [45]. This was linked to shifts in macro and megafaunal abundance and community composition and structure with lags of 4-8 months for the macrofauna [52] and 14-18 months for the megafauna [50]. Changes from the dominance of larger 
to smaller average body size was observed in the macrofauna when food supply shifted from anomalously high to lower values [52].

Monterey Bay, NE of Station M, has also been an area of time-series research in the deep-sea. Results from this area have shown the importance of mid-water fauna such as tunicates in fluxes of organic matter to the deepseafloor [54]. Other shorter-term studies have also explored physiological aspects of seabed fauna. The recent instillation of the Monterey Accelerated Research System (MARS) cabled observatory at nearly $1000 \mathrm{~m}$ depth will facilitate continued interdisciplinary research in the area, as well as the development of tools for observatory-based research.

At both the PAP and Station $M$ the macrofauna abundances changed by a factor of two to three times between years, whereas the megafauna varied by up to three orders of magnitude with most of the dominant taxa varying by at least ten fold. Abyssal megafauna may be particularly good indicators of environmental change because of the reduced complexity of the variation in resources and environmental parameters [39], [40], [45], [52] and [53].

\subsubsection{Shallow-water analogues of deep-sea environments:}

A variety of coastal systems resembles the deep-sea in some respects. These include certain Antarctic settings and marine caves [2]. The latter, in particular, may provide an assessable laboratory in which to test ideas about deep-sea temporal processes. Marine caves resemble the deep-sea in a number of respects, notably their stability, permanent darkness, low hydrodynamic energy and limited food resources, which may be equivalent to food inputs at bathyal depths. A prime example is the "3PP" cave near Marseille, France [55], where a descending profile allows density trapping of cold $\left(13-15^{\circ} \mathrm{C}\right)$ water year round. Among the species inhabiting this cave are the carnivorous sponge Asbestopluma hypogea and the hexactinellid sponge Oopsacas minuta, both also found in the bathyal Mediterranean [55). Such caves are promising settings in which to conduct in situ mesocosm experiments or temporal surveys relevant to deep-sea biology. Recent research within the framework of the MarBEF DEEPSETS project [56] and [2] has focussed on the sediment-dwelling Foraminifera and metazoan meiobenthos, both of which include species similar to those found in the deep-sea. These results may form the starting point for a temporal survey and comparisons with deep-sea time series. Drivers of temporal change in marine caves are poorly understood but likely to include temperature. There is evidence that some marine caves are being affected by the current warming trend [57]. This is likely to affect organisms (sponges in particular) that may be living near their thermal limit in "coldwater" marine caves.

\subsection{Chemosynthetic sites}

\subsubsection{Sagami Trough:}

The Sagami Bay region hosts chemosynthetic communities in the Sagami Trough, an area in the western part of the Bay that is the epicentre of frequent earthquakes and submarine volcanic activity. Continuous long-term monitoring of the seafloor communities in the "Off Hatsushima observatory" area of the Sagami Trough (1500 m depth) began in 1993. Time-series data include monitoring the many 'cold seep' communities e.g. Calyptogena-clam colonies. Analysis of Poly Chlorinated Biphenyls (PCBs) in the muscles of deep-sea mollusc species in central Sagami Bay indicated higher levels in Bathymodiolus sp., which feeds through the photosynthetic food chain, compared to Calyptogena sp., which forms part of the chemosynthetic food chain (unpublished data). This indicates that the photosynthetic food chain is more susceptible to human impacts and bioaccumulates PCBs whilst the chemosynthetic environments may be less exposed to human impacts.

\subsubsection{Haakon Mosby Mud Volcano (Nordic margin):}

Active mud volcanoes are very dynamic seafloor systems, from both the biological and geological perspective. The Haakon Mosby Mud Volcano (HMMV) is located northwest of Norway in the Barents Sea at $1250 \mathrm{~m}$ water depth. It is about $1400 \mathrm{~m}$ in diameter, has a maximum height of $10 \mathrm{~m}$ above the seafloor, and consists of several different benthic habitats. It hosts unique chemosynthetic communities, fuelled by the oxidation of methane by sulfate and further oxidation of sulfide by oxygen and nitrate. The HMMV represents an ideal natural laboratory in which to investigate the relationship between fluid flow, methane flux and benthic activity. Five cruises were carried out from 2001-2009 to investigate spatial variations in biogeochemical processes within and between the different HMMV habitats, as well as the efficiency of the biological filtering of methane and sulphide. This included obtaining the first high-resolution bathymetry map of a mud volcano in 2003, which provided the baseline for further habitat studies [58]. Long-term, interdisciplinary research at the HMMV aims at understanding the spatial scales of physical and geological phenomena of mud volcanism, the chemistry of the seep, the biodiversity and the habitat distribution of microorganisms and benthic fauna [59], [60], [61] and [62]. High-resolution in situ data on topography, hydrography, fluid and gas flow, hydrate distribution, in situ seabed temperature geochemistry, microbial rates and benthic community composition, were obtained in order to achieve a coherent understanding of the spatial 
variations of processes [63]. However, the influence of mud volcano dynamics (e.g. eruptive mud and fluid outflow, gas outbursts) on the habitat structure and distribution remains largely unknown. Recent long-term temperature records revealed a highly active centre area [61]. A long-term observatory (LOOME (Long-term Observatory On Mud-volcano Eruptions)) was deployed in summer 2009 in the framework of the EU project ESONET NoE in order to investigate in detail eruptive mud volcano phenomena, and their consequences for benthic life, as well as associated biogeochemical and physical processes. The observatory consists of several autonomous instruments recording seismic, physical and biological phenomena, and additionally a network of cabled chemical sensors and oceanographic modules. The HMMV has been a key site in several programmes including ESONET NoE, EMSO, HERMES (Hotspot Ecosystems Research on the Margins of European Seas, HERMIONE, MarBEF NoE, as well as the ESF (European Strategy Forum) EuroDEEP (Ecosystem Functioning and Biodiversity in the Deep-sea) program CHEMECO (Colonization processes in Chemosynthetic Ecosystems).

\subsubsection{Lucky Strike Deep-Sea hydrothermal vent field:}

The Lucky Strike hydrothermal vent field is located in the centre of one of the most volcanically active segments of the Mid-Atlantic ridge (MAR) and is the focus of several multidisciplinary studies since the mid90's [64] and [65]. In 2000, the InterRidge Program launched the MoMAR project (Monitoring the MidAtlantic Ridge) to coordinate long-term multidisciplinary monitoring of hydrothermal vents at MAR. This research initiative aims at studying vent environmental dynamics from geophysics to microbiology on the Lucky Strike vent field.

The prototypes developed during the European project EXOCET/D (Extreme ecosystem studies in the deep ocean Technological/Developments) (2003-2006), dedicated to the development of specific instrumentation, included TEMPO (Telecommunications Modernization Project). This autonomous ecological observatory module was designed to study the dynamics of vent mussel assemblages in relation to environmental factors [7]. TEMPO was deployed in 2006 on the Lucky Strike vent field (Fig. 3). Preliminary results show no major change in mussel community structure over the two years of the experiment. On the other hand, a significant increase of microbial coverage was observed and seems to be linked to a local modification of hydrothermal influence. TEMPO will be moored again in combination with larger-scale geophysical and geological studies during the MoMAR/D demonstration mission. The deployment of this acoustically-linked multidisciplinary observing system, with satellite connection to shore, should occur in 2010 at the Lucky Strike vent field. The Azores node, which includes the MoMAR area, was selected as one of the 11 key European observatory sites by the ESONET European observatory network. This node will allow the extension of the island's seismic and volcanic monitoring system offshore, and will provide holistic information concerning hydrothermal, coral and seamount habitats, essential for the ecosystem-based management of the region.

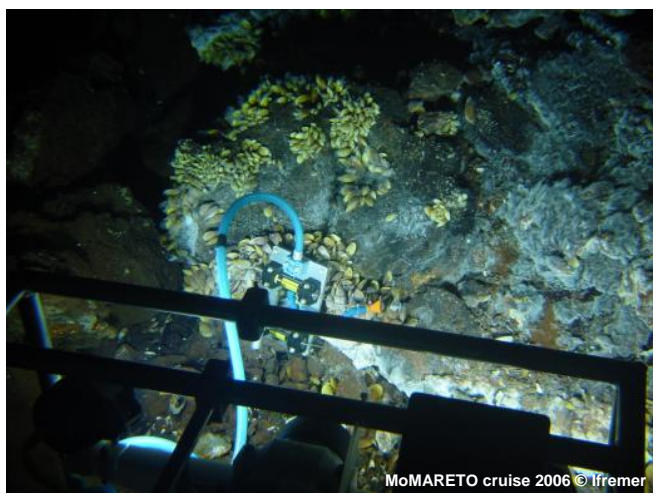

Figure 3. Rear view of the TEMPO ecological module as deployed in 2006 at the base of the Tour Eiffel edifice. The camera was looking at a Bathymodiolus azoricus assemblage for a total of 49 days. In situ chemical analysis of iron concentrations and temperature data were recorded for 6 and 18 months respectively to monitor environmental changes of abiotic conditions. MoMARETO cruise 2006, Copyright IFREMER (French Research Institute for Exploitation of the Sea/Institut Français de Recherche pour

l'Exploitation de la Mer).

Although Lucky Strike was selected as the first MAR target for long-term studies, two other vent fields, Menez Gwen and Rainbow, have also been the focus of small-scale studies of hydrothermal and biological processes. The deployment and recovery of bottom cages enabled access to the seafloor throughout the year and the identification of seasonal reproduction patterns in vent species such as Bathymodiolus azoricus [66] and [67]. Nevertheless, this method is still limited to shallow, accessible vent environments and to large megafaunal species. Another valuable approach is the use of submersible video imagery to study the temporal evolution of hydrothermal edifices [7]. A recent study has retrieved more than 14 years of imagery and environmental data to assess the temporal evolution of the Eiffel tower edifice at the Lucky Strike vent field. Preliminary data shows an overall stability of hydrothermal faunal assemblages [68] on the edifice, with small-scale modifications related to fluid exits.

Given the small amount of temporal data available, it is difficult to predict the likely impacts of global changes on hydrothermal communities. Only the further development of continuous, long-term monitoring of 
these communities will offer a high probability of capturing evidence for volcanic events, observing interactions between faulting, magmatism and hydrothermal circulations, and evaluating their impacts on the ecosystem. This is even more relevant since the Menez Gwen, Lucky Strike and Rainbow vent fields are being proposed, under the OSPAR framework, to become part of the north-eastern Atlantic network of Marine Protected Areas (MPAs).

\subsubsection{Trans-Atlantic Geotraverse}

The Trans-Atlantic Geotraverse (TAG) hydrothermal mound on the Mid-Atlantic Ridge (3600 m depth) hosts the longest-studied hydrothermal vent community in the Atlantic, first observed during submersible dives in 1985 [69]. In contrast to the changes seen at vents on fast-spreading ridges on decadal scales [11], the hydrothermal vent community at TAG has exhibited consistency in taxonomic composition and the distribution of megafauna over two decades [65]. Dense aggregations of the alvinocaridid shrimp Rimicaris exoculata occupy a central black smoker chimney complex at TAG [70], while anemones (Maractis rimicarivora) dominate the periphery of the mound.

Three factors may be responsible for the ecological constancy at TAG, which contrasts with other, more dynamic hydrothermal systems. First, geochronology of sulphides indicates that the TAG site has been intermittently hydrothermally active over the past 50,000 years [71] and [72]. Second, the comparatively large size of the TAG mound (see [73]) may buffer against the impact of fracturing and mineralisation in conduits for hydrothermal fluids, leading to decadalscale constancy in environmental parameters such as heat flux [74] and the geochemical composition of hightemperature fluids [75]. Third, one of the dominant megafaunal species at TAG (Rimicaris exoculata) is motile and capable of redistributing rapidly in response to changes in patterns of hydrothermal discharge, in contrast to the more sessile megafauna that often dominate other vent biogeographic provinces. Several studies at TAG have also documented the impacts of research activities on the vents and associated fauna (65], [76], [77] and [78). Although these results show that there are ecological consequences from research activities, they indicate that current levels of scientific activity may be sustainable. Further research at TAG provides the possibility to compare a site that appears to have decadal-scale constancy with more variable hydrothermal systems.

\section{TOWARDS A FUTURE INTEGRATED OCEAN OBSERVING SYSTEM: CONTRIBUTION OF BENTHIC BIOLOGICAL TIME-SERIES.}

\subsection{Infrastructure and platforms}

Many of the sites reviewed in this paper either have, or plan to have, an in situ infrastructure to facilitate autonomous sustained observations. In the future, it is envisaged that technological advances and societal requirements will lead to the development of enhanced infrastructure capabilities, such as cabled networks and moorings, in these and many other deep-sea settings, e.g. continental margins, abyssal plains, seamounts and mid-ocean ridges. Further development of benthic observatory programmes in a globally organized framework, such as GEOSS (Global Earth Observation System of Systems) and GOOS, represents the best available way to provide the critically needed context that can better bridge understanding between processes occurring at various spatial and temporal scales on the ocean floor and in the overlying water column. Shipbased sampling is likely to remain the main source of high-resolution data for process studies. In addition, the importance of ships for maintaining in situ infrastructure is likely to increase as more instrumentation is deployed. Technology for spatial sampling e.g. Automatic Underwater Vehicles (AUV's) (e.g. Autosub), Remotely Operated Vehicles (ROV's) (e.g. ISIS (Intermediate System to Intermediate System) at NOCS (National Oceanography Centre, Southampton), Max Rover at HCMR (Hellenic Centre for Marine Research), Victor6000 at IFREMER, and QUEST4000 at MARUM, HYPERDOLPHIN (max. dive depth 3,000m), KAIKO7000 and ABISMO (Automatic Bottom Inspection and Sampling Mobile) (max. dive depth 11,000m) at JAMSTEC (Japan Agency for Marine-Earth Science and Technology) and manned submersibles (e.g. Alvin at WHOI (Woods Hole Oceanographic Institute), Nautile at IFREMER and Thetis at HCMR) will be vital for conducting experiments. In addition, technological advances have enabled the development of submersibles and ROVs able to work at greater depths (e.g. Shinkai 6500 and Nereus). Rapid developments in technology have led to the first cabled deep-seafloor observatories led by Canadian and U.S. programmes, such as the Ocean Observatories Initiative and NEPTUNE (North East Pacific Time-series Undersea Networked Experiments) Canada. 
Complementing these cabled sea-floor observatory programmes, the astroparticle physics community are currently trialling test-beds for the future construction of an underwater neutrino telescope in the Mediterranean Sea (KM3NeT (Cubic Kilometre Neutrino Telescope)). In the future, this will result in instrumenting a cubic kilometre of seawater below the photic zone in order to detect Cherenkov light derived from cosmic neutrinos. The infrastructure will be in place for at least 10 years, logging real-time data at a very high frequency, transmitting data by cable to the shore. It is anticipated that the telescope optical sensors will detect bioluminescence, while acoustic sensors will be able to monitor bioacoustics. There is also a proposal to install Earth-Sea science junction boxes to which scientific instruments can be connected. In this way, a wide variety of sensors can be deployed to monitor the sea floor, the benthic boundary layer and the water column up to the sea surface. Thus, the KM3NeT facility will provide a unique system capable of studying benthic processes with high frequency, together with high spatial resolution sampling of the overlying body of water.

We envisage a future multi-scale approach to longterm/permanent infrastructure. This will include fixedpoint platforms e.g. cabled systems and moorings, combined with spatial samplers e.g. AUVs, ROVs and gliders, together yielding simultaneous measurement of multidisciplinary parameters at high temporal and spatial resolutions. Real-time transmission of datasets will allow continuous streams of high-resolution, multidisciplinary time-series data from the deep-sea. In some cases, responsive sampling will be possible through acoustic telemetry or cabled systems. This bidirectional communication (e.g. through cabled networks) will revolutionise deep-sea research. It will enable 'intelligent sampling', offering the ability to change the resolution or sampling strategy based on episodic events where intense sampling would be especially revealing. Sensor and sampler development will allow more parameters (particularly biological and biogeochemical) to be measured than ever before.

\subsection{Integration, coordination and collaboration}

\subsubsection{Global integration and coordination}

As an oceanographic contributor to the Global Earth Observing System of Systems (GEOSS) GOOS has now identified a lack of sustained high-resolution biological measurements and is currently starting to engage with the biological community, including deep-sea researchers. Internationally, there are many existing deep-sea (open-ocean) observation systems and networks utilizing a variety of infrastructures and technologies at various levels of development. These include:
- Water column moorings (e.g. the U.S. Ocean Observatories Initiative (OOI), OceanSITES (Ocean Sustained Interdisciplinary Timeseries Environment Observation System) international network of deepwater reference stations and EuroSITES (European Ocean Observatory Network), a European implementation of this network).

- Underwater cables (e.g. U.S. Ocean Observatories Initiative (including MARS (Monterey Bay Aquarium Research Institute)), NEPTUNE Canada, Dense Oceanfloor Network System for Earthquakes and Tsunamis (DONET), Marine Cable Hosted Observatory (MACHO), and the KM3Net project: ANTARES (Sustained Coastal Observing System for Latin America), NESTOR (Neutrino Extended Submarine Telescope with Oceanographic Research Poseidon-Pylos and NEMO-SN1 sites).

- Autonomous acoustically linked observatories (GEOSTAR (GEophysical and Oceanographic STation for Abyssal Research) 1\&2, ORION (Ocean Research Interactive Observatory Networks, Programme) ASSEM (Array of Sensors for Seabed Monitoring of geohazards), DAMOCLES/ACOBAR (Developing Arctic Modeling and Observing Capabilities for Long-term Environmental Studies/Acoustic Technology for observing the interior of the Arctic Ocean)).

- Underwater vehicles (e.g. AUVs, ROVs, manned submersibles), sensors and in situ tools.

- Seafloor observations have benefited from significant EU support over the past decade (e.g. ADIOS, MATER, BENGAL, CINCS (pelagicbenthic Coupling IN the oligotrophic Cretan Sea), ALIPOR (Autonomous Lander Instrument Packages for Oceanographic Research), GEOSTAR 1, 2, ASSEM and ORION-GEOSTAR, EXOCET/D, KM3NET, MarBEF NoE, ESONET NoE, EMSO, HERMES, and HERMIONE).

Ongoing collaborations already exist at many levels including sharing of infrastructure and platforms, in situ demonstrations, exchange of technical know-how, common data management, modelling activities (e.g. validation of global biogeochemical models), interobservatory analyses, shared knowledge transfer and outreach

\subsubsection{Industrial collaboration}

A potentially important funding source for maintaining seafloor biological time-series observations is through consortia of stakeholders involving academia, industry and end-users, including modellers and policy makers. One of the most successful examples of this is the Deepocean Environmental Long-term Observatory System (DELOS) project [79]. This is a long-term 
environmental monitoring platform in the vicinity of offshore hydrocarbon operations. DELOS was installed in January 2009 at $1400 \mathrm{~m}$ depth in the Atlantic Ocean off West Africa. It has been designed as a longterm (25-year) monitoring programme with regular (6 monthly) servicing periods using an ROV to bring instrument modules to the surface for calibration, data offloading and also to overcome problems including biofouling and failure. The DELOS system comprises two environmental monitoring platforms, one in the far field (16 km from sea floor infrastructure), and one in the near field (within $50 \mathrm{~m}$ of a sea floor well). Each platform consists of two parts - the sea floor docking station that is deployed on the sea floor at the start of the monitoring program and remains for the 25 -year project duration; and a number of observatory modules that are designed to perform specific environmental monitoring functions. In addition to DELOS, other partnerships between the hydrocarbon industry and deep-sea researchers are developing, with activity occurring on the Norwegian margin, Fram Strait, and Coast of Svalbard, Norway in conjunction with Statoil.

\subsection{Data sets: Management and users}

\subsubsection{Standardisation}

Comparisons of deep-sea biological data undertaken at both regional and global levels will require common data policies and standards across deep-sea benthic biological observations. Such standardization is essential for modeling activities, and for effective analysis and dissemination of global results and trends. Some initiatives of this type have already been attempted. For example, the DEEPSETS community, part of the MarBEF FP6 Network of Excellence, initiated the coordination of biodiversity datasets at a number of locations to enable comparisons to be made across deep-sea environments and with shallow-water sites. For multidisciplinary oceanographic measurements, the international OceanSITES programme (and European EuroSITES project) is developing a common data policy for biogeochemical and physical ocean measurements. In addition, the European project ESONET focuses efforts on standardisation, interoperability and best practice. In the U.S., the Ocean Carbon and Biogeochemistry (OCB) group has developed a common interface for data from relevant biogeochemical ocean research programmes. These common interfaces could become more widespread so that the wealth of deep-sea benthic biological data can be discovered and utilized. Several projects currently act as platforms to integrate and disseminate knowledge and expertise on marine biodiversity, linking researchers with industry, stakeholders and the general public (e.g. MarBEF, CheSS, HERMES/HERMIONE, CenSeam (Global
Census of Marine Life on Seamounts), Abyss2100, CAREX NoE). These communication networks need to be enhanced to optimise future funding opportunities.

\subsubsection{Data provision for benthic modelling}

Benthic ecosystem modellers may be a key user group for deep-sea biological datasets. However, benthic ecosystem modelling lags far behind its counterpart in the pelagic realm, largely due to insufficient temporal and spatial data to constrain model development. The emergence and integration of the time-series data outlined in section 2, coupled with techniques to determine trophic levels (e.g. [80]) and to measure processes like faunal respiration (e.g. [81]), are laying the foundation for benthic modelling to emerge as a powerful tool for understanding and predicting changes in the deep-sea. Much progress has been made with diagenetic modelling (e.g. [82] and [83]) but this only considers the biogeochemistry of sediments. In shelf environments, where data are more available and easier to obtain, attempts to model the benthos have been successful [84]. These efforts raise hopes that similar approaches may be applicable in the deep-sea, as available data continues to increase. One promising approach to benthic model development concerns the use of body size, a relatively easy, albeit labourintensive measurement to make. Allometric models have been developed in shelf systems [85] and are beginning to find deep-sea applications. Such developments, coupled with the rise in taxonomic, allometric and physiological measurements in the deepsea will ultimately lead to fully coupled benthic-pelagic ecosystem models for uses ranging from carbon sequestration to climate change.

\section{FUTURE VISION}

\subsection{The societal requirement for benthic biological ocean observation in the deep-sea}

Deep-sea benthic biological time-series are increasingly recognized as key data sets with high societal benefit and relevance. Datasets can be used to assess (un)sustainability and anthropogenic impacts, including those linked to our changing climate, to the penetration of toxic chemicals, and to activities such as fishing, mineral and hydrocarbon exploration and extraction. All these activities are set to largely increase in the deepsea. There is evidence that surface climate and fisheries can influence deep-sea ecosystems and that the impact can last for years with complex and as yet understudied feedback processes that may have global importance. In this way, deep-sea benthic biological datasets could contribute to critical societal needs in terms of disaster warning, understanding and predicting effects of climate change, and maintenance of biodiversity, ecosystem functioning, and ecosystem services. 
Despite their manifest importance, there are clearly insufficient current and projected future levels of national support for deep-sea observation and timeseries to be sustained over the longer-term in isolation from other scientific enterprises. However, the value of deep-sea observations can be increased further if they contribute towards multidisciplinary and interdisciplinary science and if the results are integrated into coordinated regional and global systems. The following are some potential societal benefits that may arise from deep-sea benthic biological time-series.

- Knowledge about the fate of carbon and other biogeochemical fluxes reaching the seafloor and the role of benthic ecosystems (biodiversity and abundance in ecosystem functioning is important for understanding the ability of the ocean to store carbon.

- Current IPCC estimates indicate that the duration of climate change will begin to overlap with the deep ocean ages of the Atlantic and Southern Ocean, so longer term carbon budgets will need to further consider deep-sea benthic ecosystem function.

- Deep-sea environments can be used to study the biological community response to changes in habitat including those driven by climate change (e.g. by continuous monitoring or in situ experiments etc).

- Deep-sea ecosystems can also be used as indicators of exchanges and changes between the atmosphere, water column, seafloor and sub-seafloor.

- More effective and environmentally sustainable governance of human activities in the deep ocean, e.g. fisheries, bio-prospecting, energy, and minerals.

Further recommendations and key scientific questions concerning deep-sea ecosystems can be found in [86].

\subsection{Next steps towards integration:}

The European Seas Observatory NETwork (ESONET) Network of Excellence and European Ocean Observatory Network (EuroSITES) are working with other observatory programs such as the US OOI, DONET, and NEPTUNE Canada to address how observatory efforts should be organized internationally, a topic also being considered by GEOSS. The EMSO programme is, in conjunction with ESONET NoE and other observatory programmes, examining the legal and fiscal aspects of operating a dispersed network of observatories around Europe, but EMSO's planning will likely be useful more broadly. The efforts of the US OOI and NEPTUNE also continue to provide influential guidance to efforts globally.
The MarBEF DEEPSETS community has identified long-term reference sites (LTBRs (Long-term Biodiversity Research)) which may form a future integrated network of deep-sea observatories. However, currently most LTBR sites are managed at a national level. DEEPSETS and similar projects are enabling communication, cross-fertilisation of ideas and standardization of data sets. In future, these sites may form the nodes of regional networks involving a number of satellite sites. In addition, to enhance sustainability and to contribute to global earth and ocean observation, seafloor observations should link with long-term water column time series such as the Continuous Plankton Recorder (SAHFOS (Sir Alister Hardy Foundation for Ocean Science), ocean observatories (time-series moorings) (e.g. EuroSITES network, ESONET-EMSO), fisheries (IFREMER, Fisheries Services Laboratory). Links also need to be made to IMBER (Integrated Marine Biogeochemistry and Ecosystem Research) and regional consortia such as EU Networks of Excellence (e.g. EUR-OCEANS (European Network of Excellence for Ocean Ecosystems Analysis).

Meanwhile, socioeconomic research on the importance of deep-sea ecosystems for human well being, on the goods and services they provide, on the values of these services and on the governance of human activities impacting on the deep-sea is developing, in conjunction with natural sciences, including long-term research. This is the case for instance for the EU funded HERMES and HERMIONE research programmes.

\section{CONCLUSION}

The wealth of data derived from global benthic biological time-series provides compelling evidence that climate forcings are impacting deep-sea ecosystems, and conversely, that deep-sea ecosystems may act as indicators of climate change. Deep-sea biological datasets are crucial for understanding ecological processes in the deep ocean, the maintenance of biodiversity, and biogeochemical cycling. This research is yielding many novel discoveries, some of which are of considerable potential benefit to society. These include bioprospecting, geo-engineering, and the response to decadal-scale climatic forcings. Long-term biological time-series are essential in order to ensure the continued development of these important areas of research and their contribution to a comprehensive and integrated global ocean observation system.

\section{ACKNOWLEDGEMENTS}

We thank the many funding agencies (namely the European Commission, the U.S. National Science Foundation) and many other National and regional funding agencies for supporting this research. Many of 
the co-authors form part of the DEEPSETS community, a working group of the European FP6 Network of Excellence MarBEF.

\section{REFERENCES}

[1] EEA International conference workshop report 'A global setting for European environmental monitoring measuring what we must manage', Copenhagen, 13-15 May 2009, accessed at: http://www.eea.europa.eu/publications/a-global-settingfor-european-environmental-monitoring-84-measuringwhat-we-must-manage

[2] Glover, A.G., Gooday, A.J., Bailey, D.M., Billett, D.S.M., Chevaldonné, P., Colaço, A., Copley, J., Cuvelier, D., Desbruyères, D., Kalogeropoulou, V., Klages, M., Lampadariou, N., Lejeusne, C., Mestre, N.C., Paterson, G.L.J., Perez, T., Ruhl, H. Sarrazin, J., Soltwedel, T., Soto, E.H., Thatje, S., Tselepides, A., Van Gaever, S., and Vanreusel, A. (2010). Climatic and geological drivers of long-term temporal change in deep-sea ecosystems. Advances in Marine Biology, 58, 1-95.

[3] van den Hove, S. and Moreau, V. (2007). Deep-Sea Biodiversity and Ecosystems: A scoping report on their socio-economy, management and governance. UNEPWCMC Cambridge, UK, pp. 84.

[4] Deuser, W. G., and Ross, E. H. (1980). Seasonal change in the flux of organic carbon to the deep Sargasso Sea. Nature 283, 364-365.

[5] Tyler, P.A. (1988). Seasonality in the Deep-Sea. Oceanography and Marine Biology 26, 227-258.

[6] Gooday, A. J. (2002). Biological Responses to Seasonally Varying Fluxes of Organic Matter to the Ocean Floor: A Review. Journal of Oceanography Volume 58, Number 22 pp. 305-332.

[7] Smith, K. L. Jr., Ruhl, H.A., Billett, D.S.M., Bett, B.J., Lampitt, R.S., (2009) Climate, carbon cycling and deepocean ecosystems. Proceedings of the National Academy of Sciences USA 106, 19211-19218.

[8] Sarrazin, J., Juniper, S.K., Massoth, G., and Legendre, P., (1999). Physical and chemical factors influencing species distributions on hydrothermal sulfide edifices of the Juan De Fuca Ridge, Northeast Pacific. Marine Ecology Progress Series 190, 89-112.

[9] Sarrazin, J., Robigou, V., Juniper, S.K., Delaney, J.R., (1997). Biological and geological dynamics over four years on a high-temperature sulfide structure at the Juan De Fuca Ridge hydrothermal observatory. Marine Ecology Progress Series 153, 5-24.

[10] Shank, T.M., Fornari, D.J., Von Damm, K.L., Lilley, M.D., Haymon, R.M., Lutz, R.A., (1998). Temporal and spatial patterns of biological community development at nascent deep-sea hydrothermal vents $\left(9^{\circ} 50^{\prime} \mathrm{N}\right.$, East Pacific Rise). Deep-Sea Research II 45, 465-515.
[11] Desbruyères, D., (1998). Temporal variations in vent communities on the East Pacific Rise and Galapagos Spreading Centre: a review of present knowledge. Cahiers de Biologie Marine 39, 241-244.

[12] Mullineaux, L.S., Peterson, C.H., Micheli, F., and Mills, S.W., (2003). Successional mechanism varies along a gradient in hydrothermal fluid flux at deep-sea vents. Ecological Monographs 73, 523-542.

[13] Levin, L. A. 2005. Ecology of cold seep sediments: Interactions of fauna with flow, chemistry, and microbes. Oceanography and Marine Biology, an Annual Review. 43, 1-46.

[14] Jørgensen, B.B. and Boetius, A., (2007). Feast and famine - microbial life in the deep-sea bed. Nature Microbiology Reviews 5, 770-781.

[15] Pacala S. and Kinzig A.P. (2002). Introduction to theory and the common ecosystem model. In: Kinzig, A.P., Pacala, S.W., Tilman, D. (eds) Functional Consequences of Biodiversity: Empirical Progress and Theoretical Extensions. Princeton University Press, Princeton, US. pp 169-74. Cited in van den Hove and Moreau 2007.

[16] Danovaro, R., Gambi, C., Dell'Anno, A., Corinaldesi, C., Fraschetti, S., Vanreusel, A., Vincx, M., Gooday, A.J. (2008), Exponential decline of Deep-Sea Ecosystem Functioning Linked to Benthic Biodiversity loss. Current Biology 18, 1-8.

[17] Roberts, C.M. (2002). Deep impact: the rising toll of fishing in the deep-sea. Trends in Ecology and Evolution 17(5), 242-245.

[18] Bensch, A., Gianni, M., Gréboval, Sanders, J. Hjort, A. (2008). Worldwide review of bottom fisheries in the high seas. Technical Paper 522. UN Food and Agriculture Organisation. Rome, Italy. pp 157.

[19] Fontanier, C., Jorissen, F.J., Chaillou, G., David, C., Anschutz, P., Lafon, V. (2003). Seasonal and interannual variability of benthic foraminiferal faunas at $550 \mathrm{~m}$ depth in the Bay of Biscay. Deep-Sea Research Part 1 50(4), 457-494.

[20] Fontanier, C., Mackensen, A., Jorissen, F., Anschutz, P., Licari, L., Griveaud, C. (2006). Stable oxygen and carbon isotopes of live benthic foraminifera from the Bay of Biscay: Microhabitat impact and seasonal variability Marine Micropaleontology, pp. 159-183.

[21] Ohga, T. and Kitazato, H., (1997) Seasonal changes in bathyal foraminiferal populations in response to the flux of organic matter (Sagami Bay, Japan). Terra Nova 9 , 33-37.

[22] Kitazato, H., Shirayama, Y., Nakatsuka, T., Fujiwara, S., Shimanaga, M., Kato, Y., Okada, Y., Kanda, J., Yamaoka, A., Masuzawa, T. and Suzuki, K. (2000). Seasonal phytodetritus deposition and responses of bathyal benthic foraminiferal populations in Sagami Bay, Japan: preliminary results from "Project Sagami 1996-1999. Marine Micropaleontology 40, 135-149. 
[23] Kitazato, H; Nakatsuka, T; Shimanaga, M., Kanda, J., Soh, W., Kato, Y., Okada, Y., Yamaoka, A., Masuzawa, T., Suzuki, K. and Shirayama, Y. (2003). Long-term monitoring of the sedimentary processes in the central part of Sagami Bay, Japan: rationale logistics and overview of results. Progress in Oceanography. 57 316.

[24] Managaki, S., Takada, H., Kim, D.M. et al. (2006) Threedimensional distributions of sewage markers in Tokyo Bay water - fluorescent whitening agents (FWAs). Marine Pollution Bulletin 52, 281-292.

[25] Canals, M., P. Puig, X. Durrieu de Madron, S. Heussner, A. Palanques and J. Fabrés. (2006). Flushing submarine canyons. Nature 444, 354-357.

[26] Company, J. B., Puig, P., Sardá, F., Palanques, A., Latasa, M. and Scharek R. (2008). Climate Influence on Deep-sea Populations, PLoS ONE 3(1): e1431: 1-8.

[27] Maynou, F. (2008) Influence of the North Atlantic Oscillation on Mediterranean deep-sea shrimp landings. Climate Research 36, 253-257.

[28] Danovaro, R., Dell'Anno, A., Fabiano, M., Pusceddu, A. and Tselepides, A. (2001). Deep-Sea ecosystem response to climate changes: the Eastern Mediterranean case study. Trends in Ecology and Evolution 16, 505510 .

[29] Lampadariou N, Tselepides A, Hatziyanni E. (2009). Deep-sea meiofaunal and foraminiferal communities along a gradient of primary productivity in the eastern Mediterranean Sea. Scientia Marina 73,337-345.

[30] Danovaro, R., Dell'Anno, A., Pusceddu, A., (2004) Biodiversity response to climate change in a warm deepsea. Ecology Letters 7, 821-828.

[31] Tselepides, A., Akoumianaki, I. and Polychronaki, T. Organic matter variability in sediments of the Aegean Sea. In Proceedings of the 6th Hellenic Symposium on Oceanography and Fisheries. 2000.

[32] Tselepides, A and Lampadariou, N. (2004) Deep-sea meiofaunal community structure in the Eastern Mediterranean: are trenches benthic hotspots? Deep-Sea Research I 51, 833-847.

[33] Kröncke, I., Türkay, M. and Fiege, D. (2003) Macrofauna communities in the Eastern Mediterranean deep-sea. Marine Ecology 24, 193-216.

[34] Soltwedel, T., Bauerfeind, E., Bergmann, M., Budaeva, N., Hoste, E., Jaeckisch, N., von Juterzenka, K., Matthiessen, J., Mokievsky, V., Nöthig, E.-M., Quéric, N.-V., Sablotny, B., Sauter, E., Schewe, I., UrbanMalinga, B., Wegner, J., Wlodarska-Kowalczuk, M. and Klages, M. (2005). HAUSGARTEN: Multidisciplinary Investigations at a Deep-Sea, Long-Term Observatory in the Arctic Ocean. Oceanography 18, 47-61.

[35] Hassol, S.J., (2004). Impacts of a warming Arctic: Arctic Climate Change Assessment. Cambridge University Press, pp.139.
[36] Bauerfeind, E., Nöthig, E.-M., Beszczynska, A., Fahl, K. Kaleschke, L., Kreker, K., Klages, M., Soltwedel, T., Lorenzen, C., Wegner, J. (2009). Particle sedimentation patterns in the Eastern Fram Strait $\left(79^{\circ} \mathrm{N} / 4^{\circ} \mathrm{E}\right)$ during 2000-2005. Results from the arctic long-term observatory HAUSGARTEN. Deep-Sea Research I. 56, 1471-1487.

[37] Hoste, E., Vanhove, S., Schewe, I., Soltwedel, T. and Vanreusel, A. 2007. Spatial and temporal variations in deep-sea meiofauna assemblages in the Marginal Ice Zone of the Arctic Ocean. Deep-sea Research I 54, 109129.

[38] Lampitt, R.S., Salter, I., de Cuevas, B.A., Hartman, S., Larkin, K.E. and Pebody, C.A., (2010). Long-term variability of downward particle flux in the deep Northeast Atlantic: causes and trends. Deep-sea Research II 57 (15), 1346-1361.

[39] Wigham, B.D., Hudson, I.R., Billett, D.S.M. and Wolff, G.A., (2003). Is long-term change in the abyssal Northeast Atlantic driven by qualitative changes in export flux? Evidence from selective feeding in deep-sea holothurians. Progress in Oceanography 59, 409-441.

[40] Billett, D.S.M., Bett B.J., Reid, W.D.K., Boorman, B. and Priede, M. (2010). Long-term change in the abyssal NE Atlantic: The 'Amperima Event' revisited. Deep-sea Research Part II 57(15), 1406-1417.

[41] Kalogeropoulou, V., Bett, B.J., Gooday, A.J., Lampadariou, N., Martinez Arbizu, P. and Vanreusel, A., (2010). Temporal changes (1989-1999) in deep-sea metazoan meiofaunal assemblages on the Porcupine Abyssal Plain, NE Atlantic. Deep-Sea Research II 57(15), 1383-1395.

[42] Soto, E.H., Paterson, G.L.J., Billett, D.S.M., Hawkins, L.E., Galéron, J. and Sibuet, M., (2010). Temporal variability in polychaete assemblages of the abyssal NE Atlantic Ocean. Deep-Sea Research II 57(15), 13961405.

[43] Soto, E.H. (2009). Taxonomy and biology of deep-sea polychaetes: Temporal variability in polychaete assemblages of the abyssal NE Atlantic Ocean. PhD Thesis, University of Southampton, $278 \mathrm{pp}$.

[44] Gooday, A.J., Malzone, M.G., Bett, B.J. and Lamont, P.A., (2010s). Decadal-scale changes in shallowinfaunal foraminiferal assemblages at the Porcupine Abyssal Plain, NE Atlantic. Deep-sea Research Part II 57(15)1362-1382.

[45] Smith, K.L., Baldwin, R.J., Ruhl, H.A., Karru, M., Mitchell, B.G. and Kaufmann, R.S., (2006). Climate effect on food supply to depths greater than 4,000 metres in the northeast Pacific. Limnology and Oceanography, 51, 166-176.

[46] FitzGeorge-Balfour, T., Billett, D.S.M., Wolff, G.A., Thompson, A., Hudson, I.R. and Tyler, P.A., (2010). Phytopigments as biomarkers of selectivity in abyssal holothurians; inter-species differences in responses to a changing food supply. Deep-Sea Research II 57(15), 1418-1428. 
[47] Bailey, D.M., Collins, M.A., Gordon, J.D.M., Zuur, A.F., Priede, I.G., (2009). Long-term changes in deep-water fish populations in the North East Atlantic: a deeperreaching effect of fisheries? Proceedings of the Royal Society B: Biological Sciences, Online: doi:10.1098/rspb.2009.0098.

[48] Caso, M., Pisanty, I. and Ezcurra, E. 2004. Diagnostico Ambiental del Golfo de México. INE-Semarnat, México, pp. 626.

[49] Bryant, W. R., Lugo, J., Cordova, C., and Salvador, A. (1991). Physiography and bathymetry. In: Salvador, A. (Ed.), The Gulf of Mexico Basin. Boulder CO. The Geological Society of America, U.S.A, pp. 13-30.

[50] Escobar-Briones, E., and García-Villobos, F.J. (2009). Distribution of total organic carbon and total nitrogen in sediments from the deep-sea Southwestern Gulf of Mexico. Boletìn de la Sociedad Geológica Mexicana 61 , 73-86.

[51] Aller, J. Y. (1997). Benthic community response to temporal and spatial gradients in physical disturbance within a deep-sea western boundary region. Deep-Sea Research I 44, 39-69.

[52] Ruhl, H.A., Ellena, J.A. and Smith, K.L., Jr., 2008. Connections between climate, food limitation, and carbon cycling in abyssal sediment communities, Proceedings of the National Academy of Sciences USA 105, 17006-17011.

[53] Ruhl, H.A. and Smith, K.L., (2004). Shifts in deep-sea community structure linked to climate and food supply. Science 305, 513-515.

[54] Robinson, B.H., Reisenbichler, K.R. and Sherlock, R.E. (2005). Giant larvacean houses: rapid carbon transport to the deep-seafloor. Science 308:1609-1611.

[55] Vacelet, J., Boury-Esnault, N. and Harmelin, J.G. (1994). Hexactinellid Cave, a unique deep-sea habitat in the scuba zone. Deep-Sea Research I 41, 965- 973.

[56] Chevaldonné, P., Pérez, T., Boury-Esnault, N., Harmelin, J.G., Lejeusne, C., Zibrowius, H., Vacelet, J., Lampadariou, N., Janssen, A. and Martínez Arbizu, P. (2008). Shallow marine caves as mesocosms of the deep-sea: the «3PP cave » example. World Conference on Marine Biodiversity, 11-15 November 2008, Valencia, Spain.

[57] Chevaldonné, P. and Lejeusne, C. (2003). Regional warming-induced species shift in north-west Mediterranean marine caves. Ecology Letters 6, 371379.

[58] Foucher, J.-F., Westbrook, G.K., Boetius, A., Ceramicola, S., Dupre, S., Mascle, J., Mienert, J., Pfannkuche, O., Pierre, C. and Praeg, D. (2009). Structure and Drivers of Cold Seep Ecosystems. Oceanography 22, 92-109.

[59] Jerosch, K., Schluüter, M., Foucher, J.P., Allais, A.-G., Klages, M. and Edy., C., (2007). Spatial distribution of mud flows, chemoautotrophic communities, and biogeochemical habitats at Håkon Mosby Mud Volcano. Marine Geology 243, 1-17.
[60] De Beer, D., Sauter, E., Niemann, H., Kaul, N., Foucher. J.P., Witte. U., Schlüter, M. and Boetius, A., (2006). In situ fluxes and zonation of microbial activity in surface sediments of the Håkon Mosby mud volcano. Limnology and Oceanography 51, 1,315-1,331.

[61] Feseker, T., Foucher, J.P. and Harmegnies, F., (2008). Fluid flow or mud eruptions? Sediment temperature distributions on Håkon Mosby mud volcano, SW Barents Sea slope. Marine Geology 247,194-207.

[62] Schlüter, E., Muyakshin, S.I., Charlou, J.L., Schlüter, M., Boetius, A., Jerosch, K., Damm, E., Foucher, JP. and Klages, M. (2006). Methane discharge from a deep-sea submarine mud volcano into the upper water column by gas hydrate-coated methane bubbles. Earth and Planetary Science Letters 243, 354-365.

[63] Niemann H., Lösekann, T., de Beer, D., Elvert, M., Nadalig, T., Knittel, K., Amann, R., Sauter, E.J., Schluüter, M., Klages, M., et al., (2006). Novel microbial communities of the Haakon Mosby mud volcano and their role as methane sink. Nature $\mathbf{4 4 3}$, 854-858.

[64] Desbruyères, D., Almeida, A., Biscoito, M., Comtet, T., Khripounoff, A., Le Bris, N., Sarradin, P.M., and Segonzac, M., (2000). A review of the distribution of hydrothermal vent communities Along the northern Mid-Atlantic Ridge: dispersal vs. environmental controls. Hydrobiologia 440, 201-216.

[65] Copley, J.T.P., Jorgensen, P.B.K and, Sohn, R.A. (2007). Assessment of decadal-scale ecological change at a deep Mid-Atlantic hydrothermal vent and reproductive timeseries in the shrimp Rimicaris exoculata. Journal of the Marine Biological Association of the UK, 84, 859-867.

[66] Colaço A., Martins I, Laranjo, M. Pires, L., Leal, A., Prieto, C., Costa, V., Lopes, H., Rosa, D., Dando, P.R. and Serrão-Santos R. (2006). Annual spawning of the hydrothermal vent mussel, Bathymodiolus azoricus, under controlled aquarium, conditions at atmospheric pressure. Journal of Experimental Marine Biology and Ecology 333, 166-171.

[67] Colaço A., Prieto, C., Martins A, Figueiredo, M. Lafon, V., Monteiro, M. and Bandarra N. (2009). Seasonal variations in lipid composition of the hydrothermal vent mussel. Marine Environmental Research 67, 146-152.

[68] Cuvelier, D., Sarrazin, J., Colaço, A., Copley, J., Desbruyères, D., Glover, A., Tyler, P. and Serrão Santos, R. (2009). A first decadal study (1994-2008) of community dynamics on an Atlantic hydrothermal edifice as revealed by high-resolution video image analysis. 4th International Symposium on Chemosynthesis-Based Ecosystems, Okinawa, Japan, 29June-3July 2009.

[69] Rona, P.A., Klinkhammer, G., Nelsen, T.A., Trefry, J.H. and Elderfield, H., (1986). Black smokers, massive sulphides and vent biota at the Mid-Atlantic Ridge. Nature 321, 33-37.

[70] Van Dover, C.L. (1995). Ecology of Mid-Atlantic Ridge hydrothermal vents. In: Parson, L.M., Walker, C.L., Dixon, D.R. (Eds.), Hydrothermal vents and processes, 
Spec Publication 87. Geological Society, London, pp. 257-294.

[71] Lalou, C., Reyss, J.L., Brichet, E., Arnold, M., Thompson, G., Fouquet, Y. and Rona, P.A., (1993). New age data for Mid-Atlantic Ridge hydrothermal vents sites: TAG and Snake Pit chronology revisited. Journal of Geophysical Research 98, 9705-9713.

[72] You, C.F. and Bickle, M.J., (1998). Evolution of an active sea-floor massive sulphide deposit. Nature 394, 668-671.

[73] Humphris, S.E., Herzig, P.M., Miller, D.J., Alt, J.C., Becker, K., Brown, D., Brugmann, G., Chiba, H., Fouquet, Y., Gemmell, J.B., Guerin, G., Hannington, M.D., Holm, N.G., Honnorez, J.J., Iturrino, G.J., Knott, R., Ludwig, R., Nakamura, K., Petersen, S., Reysenback, A.-L., Rona, P.A., Smith, S., Sturz, A.A., Tivey, M.K. and Zhao, X. (1995). The internal structure of an active sea-floor massive sulphide deposit. Nature 377, 713-716.

[74] Wichers, S., Sohn, R.A. and Terray, G., (2005). New constraints on the thermal power of the TAG hydrothermal system and the dynamics of the water column plume. Eos, Transactions of the American Geophysical Union, 86, Fall Meeting Supplement, Abstract, OS33A-1466.

[75] Parker, C.M., Von Damm, K.L., Beers, K.A., Green, D.R., Alker, B.J. and German, C.R., (2005). Time series fluid compositions from the TAG hydrothermal mound, MAR: 1986-2004. Eos, Transactions of the American Geophysical Union, 86, Fall Meeting Supplement, Abstract OS22A-07.

[76] Copley, J.T.P., Tyler, P.A., Van Dover, C.L., Schultz, A., Dickson, P., Singh, S. and Sulanowska, M., (1999). Subannual temporal variation in faunal distributions at the TAG hydrothermal mound (26N, Mid-Atlantic Ridge). P.S.Z.N.: Marine Ecology, 30, 291-306.

[77] Herring, P.J., Gaten, E. and Sheldon, P.M.J., (1999). Are vent shrimps blinded by science? Nature 398, 116.

[78] Johnson, M. (2005). Oceans need protection from scientists too. Nature $\mathbf{4 3 3}, 105$.

[79] Bagley, P.M., Smith, K.L., Jr., Bett, B., Priede, I.G., Rowe, G., Clarke, J. and Walls, A. (2007). Deep-ocean Environmental Long-term Observatory System (DELOS):- Long-term (25 year) monitoring of the deepocean animal community in the vicinity of offshore hydro carbon operations, OCEANS 2007 - Europe, art. No. 4302250.

[80] Iken, K., Brey, T., Wand, U., Voigt, J. and Junghans, P. (2001). Food web structure of the benthic community at the porcupine abyssal plain (NE Atlantic): A stable isotope analysis. Progress in Oceanography 50, 383-405.

[81] Woulds, C., Andersson, J.H., Cowie, G.L., Middelburg, J.J. and Levin, L.A. (2009). The short-term fate of organic carbon in marine sediments: Comparing the Pakistan margin to other regions. Deep-Sea Research II 56, 393-402.
[82] Soetaert, K., Herman, P.M.J. and Middelburg, J.J. (1996). A model of early diagenetic processes from the shelf to the abyssal depths. Geochimica et Cosmochimica Acta 60, 1019-1040.

[83] Kelly-Gerreyn, B.A., Hydes, D.J., Trimmer, M. and Nedwell, D.B. (1999). Calibration of an early diagenesis model for high nitrate, low reactive sediments in a temperate latitude estuary (Great Ouse, UK). Marine Ecology Progress Series, 177, 37-50.

[84] Van Oevelen, D., Soetart, K., Middelburg, J.J., Herman, M.J., Moodley, L., Hamels, I., Moens, T. and Heip, C.H.R. 2006. Carbon flows through a benthic food web: Integrating biomass, isotope and tracer data. Journal of Marine Resources 64, 453-482.

[85] Blanchard, J.L., Jennings, S., Law, R., Castle, M.D., McCloghrie, P., Rochet, M.J. and Benoit, E. (2009). How does abundance scale with body size in coupled size-structured food webs? Journal of Animal Ecology 78, 270-280.

[86] The Deep-Sea Frontier: Science Challenges for a Sustainable Future' (European Consortium of Ocean Drilling, 2008). European Commission EUR 22812, pp. 53. 